\title{
An Investigation About High School Students' Mathematics Anxiety Level According To Gender
}

\author{
Kamil Akbayır \\ Correspondence: Kamil Akbayır Yüzüncü Yıl University, Faculty of Education, Department of Mathematic and Science \\ Education, Elementary Mathematic Education, Van, Turkey.
}

\author{
Received: April 8, $2019 \quad$ Accepted: May 15, $2019 \quad$ Online Published: May 20, 2019 \\ doi:10.11114/jets.v7i7.4201 URL: https://doi.org/10.11114/jets.v7i7.4201
}

\begin{abstract}
The aim of this study is to investigate the anxiety levels of high school students towards mathematics lesson according to gender variable. A total of 89 ninth grade students ( 29 females and 60 males) from various high schools were enrolled in Van province center in the 2017-2018 academic year. In the study, the data were collected by using the developed "Mathematical Anxiety Scale" of the researcher. In the analysis of the collected data, frequency and percentage values were taken and independent sample t test was used. According to the results of the study, high school students' mathematics anxiety levels were at medium level. In addition, there were no statistically significant differences in the anxiety levels of female and male students. While the test anxiety levels of the students who participated in the study were higher than the other anxiety levels, the lowest anxiety level was seen as lack of curriculum subjects.
\end{abstract}

Keywords: mathematics anxiety, high school student, teacher attitude

\section{Introduction}

In recent years, mathematics anxiety has emerged as a common phenomenon experienced between primary school students and university students (Peker \& Şentürk, 2012). The anxiety, which is a feeling gained through the conditioning of learning-oriented theories, sometimes encourages people to engage in creative-constructive behavior with impulse and in some cases prevents such behaviors (Dursun \& Bindak, 2011). Mathematical thinking ability; students to receive information systematically, make logical predictions, reasonable and accurate comparisons and can make inferences. Therefore, it can be said that the success of the students in the mathematics course will contribute positively to the other courses. In addition, mathematical skills are one of the keys to the success of students in their daily lives (Alkan, 2011). However, the fact that mathematical concepts are abstract and can not be related to daily life by students, and the lack of qualified learning-teaching environments in mathematics education make it difficult to learn the subjects of mathematics, which leads to negative emotions towards mathematics in students (Aydın \& Keskin, 2017). An interesting subject for mathematicians and mathematics educators is the mathematics anxiety; Richardson and Suinn (1972) describe the use of numbers in daily life and academic studies and the sense of tension and anxiety that prevents the solution of mathematical problems. It is stated that mathematics anxiety may prevent their mathematics achievement among students and cause tensions in daily tasks such as counting money, checking bank account, evaluating sales prices, sharing workload among students (Richardson \& Suinn, 1972). Mathematics anxiety is a multi-faceted structure and is intertwined with concepts such as fear, contemplation and uneasiness (Baloglu, 2001). Davarcioğlu (2008), in his research on the fear of mathematics, explained fear as a feeling of excitement, and fear turned into bodily reactions, such as trembling, flushing, not breathing, heart palpitations, fainting, and so forth. He also stated that mathematical anxiety was the result of his being physically exposed to situations. Aydin et al. (2009) stated that anxiety was a threatened state of fear and tension, and that it was a result of conflict and prevention in individuals, most of the time they stated that they reflect an unknown internal tension and uneasiness. It is stated that mathematics anxiety, which is a disturbing situation on the students, causes the student to be afraid of the course, not to participate in the activities related to the course in time, to decrease the rate of learning with the increase of panic and uneasiness and to hate the mathematics in a continuous failure (Alkan, 2010).

Anxiety is defined as a state of uneasiness and anxiety felt by the individual in a general threatening situation (Scovel, 1991; Isık, 1996). Despite its negative aspects, anxiety has stimulating, protective and motivating characteristics of the organism. Persons who prepare themselves against injury, pain, punishment, separation and frustration are the examples that can be given to the motivating characteristics when the anxiety is stimulating and taking precautions, and if it is 
negative, it is easier to overcome the fear of being protective and unsuccessful. Because of these characteristics, Allwright and Bailey (1991) argue that anxiety is not really a feeling to be avoided.

Anxiety is often described as a feeling of discomfort (Başarır, 1990). A normal level of anxiety can help people to feel desire, to make decisions, to generate energy in line with the decisions taken, and to improve their performance using this energy. For example, a mid-level concern for a conference helps us better prepare for this conversation and perform better. In cases where we have no anxiety, the result is usually negative, since there is no desire to do the job to be done as well as we can. However, if the anxiety is very intense, it is prevented that the person uses his / her energy efficiently and directs his / her attention and power to the work he / she will do. The person can not use the full potential and reach the desired performance (Dursun \& Bindak, 2011).

The main source of anxiety in students is the fear of failure and the loss of self-respect that comes with it. Anxiety can adversely affect students' performance in a number of ways. Anxious students may have difficulty in learning and have difficulty in transferring and using their knowledge. The most common form of anxiety that makes the individual powerless is mathematics anxiety (Pintrich \& Schunk, 2002). It is also wrong to link the emergence and development of mathematics anxiety only to the student or the nature of mathematics. Factors such as the working conditions of the student at home and the learning environments in the school, the socio-economic status of the family and the level of education, teacher behaviors, and the quality of teaching are among the factors affecting the mathematics anxiety (Taylor \& Fraser, 2003).

The fear and anxiety of mathematics begin from the first years of student life. Mothers and fathers can be the model by transferring their fears to their children consciously or unconsciously. Parents, who are models, say that mathematics is difficult, people are afraid of mathematics, while at the same time they say that mathematics skills are very important for a person to be successful in the future (Thomas, 1998).

In many studies on the effects of mathematics anxiety, the results of mathematical anxiety of individuals with mathematics anxiety, mathematical success, avoidance of mathematics courses, limitation of career and career choices, guilt and shame were reported (Byrd, 1982; Erktin et al., 2006; Ma, 1999; Richardson \& Suinn, 1972; Suinn \& Edwards, 1982; Tobias \& Weissbrod, 1980). The relationship between mathematics anxiety and mathematics achievement could not be clearly stated in the literature (Baloglu, 2004a; Reyes, 1984). Although many studies have found a negative relationship between these two variables (Hembree, 1990; Ma, 1999; Miller \& Bichsel, 2004; Reyes, 1984; Suinn \& Edwards, 1982; Tobias \& Weisbrod, 1980), some studies have not shown a remarkable relationship (Fennema \& Sherman, 1976; Richardson \& Suinn, 1972). Especially, in previous mathematics lessons, performance, mathematics attitude and mathematical self-concept are controlled, and the effect of mathematics anxiety is meaningless or diminished (Fennema \& Sherman, 1976).

Although mathematics lesson is a lesson that is faced by students at almost every level from primary to university, it is perceived as a difficult lesson to be learned by many students. This situation causes students to develop negative attitudes towards mathematics lesson and consequently decrease their success (Kurbanoğlu \& Takunyac1, 2012). Mathematics achievement is seen as an important factor in the professional development of students (Olkun et al., 2005). It is seen that student and teacher candidates and even teachers have negative attitudes towards mathematics and that mathematics is perceived by many individuals as an area that is difficult to teach and learn (Delice et al., 2009). There is an important role for students to develop positive attitudes towards mathematics lesson and to increase their success (Peker \& Mirasyedioğlu, 2003). Mathematics anxiety was defined as feeling anxiety and tension feelings in daily and academic life by solving mathematics problems and using numbers (Bindak, 2005b). Mathematics anxiety is a vital phenomenon of vital importance from primary to university (Newstead, 1998; Yüksel-Şahin, 2008; Vinson, 2001; Uusimaki \& Nason, 2004).

In a significant part of the studies on mathematics anxiety, the factors that cause anxiety were determined and classified. According to Lazarus (1974), mathematics anxiety is a concept that arises from the interaction of many factors. Berebitsky (1985) showed that teachers who are not proficient in mathematics, who have mathematics anxiety, abstract, symbolize, and mathematical rules are among the factors that make up the mathematics anxiety. Harris and Harris (1987) categorized the factors that could lead to mathematics fear and anxiety on three main axes: student-related, teacher-related and teaching-related (cited in: Baloğlu, 2001), Byrd (1982) explained the causes of mathematics anxiety; classified as situational, personality and personal reasons. The teaching methods used in mathematics education and the effects of mathematics teachers on students; attitude towards mathematics, personality reasons; gender, age and ethnicity can be given as examples of personal reasons (Baloğlu, 2001).

A significant part of the research on mathematics anxiety is the gender difference, which is one of the personal factors. In some studies, girls are reported to carry more mathematics anxiety than boys (İlhan \& Sünkür, 2013; Akgün et al., 2007; Arı et al., 2010; Baloğlu, 2004; Ergene, 2011; Şahin, 2008; Baloğlu, 2004b; Baloglu \& Kocak, 2006; Hemree, 
1990; Miller \& Bichsel, 2004), in some studies (Peker \& Şentürk, 2012; Uysal \& Selışı, 2016; Dursun \& Bindak, 2011), the anxiety levels of men are higher. Research showing that there is no significant relationship between gender and mathematics anxiety and overlapping with our study (Ma, 1999; Yüksel-Şahin, 2004; Arıkan, 2004; Aydın, 2011; Gierl \& Bisanz, 1995; Lussier, 1996; Dede \& Dursun, 2008; Dursun \& Bindak, 2011; Aydın \& Keskin, 2017; Eskici \& Ilgaz, 2019; Aydın, 2011; Taşdemir, 2015; Yücel \& Koç, 2011; Adal \& Yavuz, 2017; Tuncer \& Yılmaz, 2016; Küçük Demir et al., 2016) it is also possible to come across. As a result of the literature review, it is seen that mathematics anxiety is an important affective factor closely related to many subjects ranging from attitude towards mathematics to success, from avoiding mathematics to career and career choice. In this context, it is important to determine the mathematics anxiety levels of the students and to examine them according to various variables.

\section{Method}

The research was designed in the relational survey model. The relational research model is a research model that aims to determine the presence or degree of coexistence between two or more variables (Karasar, 2005). In this study, the relationship between gender anxiety and gender was investigated.

\subsection{Working Group}

The universe of the study consists of the ninth grade students attending various high schools in the 2017-2018 academic year in the city of Van. The random sampling method was used to determine the research sample. The study group consisted of 89 students (29 females and 60 males) studying in state high schools in Van.

Table 1. Distribution of the participant students by gender

\begin{tabular}{lll}
\hline Gender & f & $\%$ \\
\hline Female & 29 & 32.6 \\
Male & 60 & 67.4 \\
Total & 89 & 100 \\
\hline
\end{tabular}

\subsection{Data Collection Tools}

In order to collect data, "Mathematics Anxiety Scale" developed for high school students was used by the researcher. During the preparation process of the scale, high school students' thoughts about teaching mathematics subjects in the curriculum have been taken. A total of 27 items were prepared to be included in the scale in the light of the opinions and researchers obtained from the students. Based on these items, three experts and 10 final year students were selected and the items which were suitable for being included in the scale were selected. Thus, from the 27 items that were initially found, 20 items were selected and the scale was finalized by subtracting similar substances which did not serve the purpose.

The reliability coefficient of the scale was calculated as .725. The answer options and scoring of the items in the scale are "agree $=1$ ", "undecided $=2$ " and "disagree $=3$ ". Likert-type and three-graded scale indicates the low level of anxiety. The lowest score that can be obtained from this scale is 20 and the highest score is 60 .

The scale was analyzed according to the mathematics anxiety states of the students participating in the study, the mathematics anxiety states according to their gender and whether the mathematics anxiety changes according to gender, the attitudes towards textbooks, the teachers, the exams, the lack of secondary school subjects and the sub-factors such as the concern for the curriculum.

\subsection{Data Analysis}

Data were analyzed manually by the researcher. In the analysis of data, frequency and percentage values were taken and independent sample $t$ test was used. The significance level was taken as $\mathrm{p}=.05$ in all analyzes.

\section{Results}

In this section, the main problem of the research and its sub-problems will be given.

\subsection{Mathematics Anxiety Levels of Students}

Mathematics anxiety scores of high school students participating in the study are presented in table 2 .

Table 2. Mean and standard deviation of students' mathematics anxiety scores

\begin{tabular}{ccccc}
\hline $\mathrm{N}$ & Lowest score & Highest score & $\bar{X}$ & Std. Dev. \\
\hline 89 & 25 & 57 & 42.82 & 6.48 \\
\hline
\end{tabular}


When table 2 is examined, the mathematics anxiety scores of the 89 high school students who applied the scale ranges from 25 to 57 points as seen in table 2 and the mean score of anxiety was 42.82 . Considering the calculation of the students' anxiety level, the average range of the scale is taken into consideration by calculating the range width / number of groups to be performed (Tekin, 1993). High anxiety level between 20-33.3, moderate anxiety between 33.4-46.7 and 46.8-60 was interpreted as no anxiety. According to this, it can be said that the anxiety levels of the students who participated in the research were moderate.

Table 3. Descriptive statistics about mathematics anxiety scale items

\begin{tabular}{llll}
\hline Substances & $\mathrm{N}$ & $\bar{X}$ & $\begin{array}{c}\text { Std. } \\
\text { Dev. }\end{array}$ \\
\hline 1. I don't know the importance of mathematics & 89 & 2.11 & .89 \\
2. I have difficulty when the lesson is based on memorization. & 89 & 2.31 & .78 \\
3. Our class is very crowded. & 89 & 2.32 & .76 \\
4. The topics in our book have been covered much above our level & 89 & 2.51 & .64 \\
5. New developments in mathematics are not included in the curriculum. & 89 & 2.00 & .88 \\
6. I have a lot of difficulty in mathematics exams. & 89 & 1.27 & .60 \\
7. We have insufficient mathematical tools. & 89 & 2.27 & .56 \\
8. I am inadequate in secondary school about the subjects of mathematics. & 89 & 1.99 & .79 \\
9. Books are insufficient in terms of print quality. & 89 & 2.15 & .83 \\
10. Books are insufficient in terms of content. & 89 & 1.92 & .80 \\
11. I don't find mathematics topics interesting. & 89 & 2.39 & .73 \\
12. Books often change. & 89 & 2.22 & .87 \\
13. Subjects do not grow during the teaching period. & 89 & 2.20 & .77 \\
14. Our teacher is inadequate in terms of teaching methods. & 89 & 2.44 & .75 \\
15. Our teacher is insufficient in terms of measurement and evaluation & 89 & 2.31 & .83 \\
techniques. & & & \\
16. Our teacher is inadequate in the curriculum. & 89 & 2.66 & .65 \\
17 Our teacher does not practice in every way. & 89 & 2.34 & .82 \\
18. There is no connection between the subjects of mathematics and our daily & 89 & 1.79 & .76 \\
life. & & & \\
19. I do not find mathematics interesting. & 89 & 2.56 & .70 \\
20. Mathematics textbooks give more weight to abstract concepts. & 89 & 1.91 & .73
\end{tabular}

When table 3 is examined, it is seen that the averages of 20 items directed to the students are examined separately, while the lowest average is 1.27 with the test anxiety factor while the highest with 2.66 is the lack of curriculum subjects. In other words, the level of test anxiety of the students participating in the research is higher than the other anxiety levels. The lowest level of anxiety was also seen as a concern for the lack of curriculum subjects.

\subsection{Student's Mathematics Anxiety Differences by Gender}

In order to determine whether there is a difference between the anxiety levels of the male and female students, t-test was conducted with the anxiety scale and independent groups.

Table 4. T-test results of mathematics anxiety scores according to gender of students

\begin{tabular}{lllcccc}
\hline Gender & $\mathrm{N}$ & $\bar{X}$ & Std. Dev. & Free. Deg. & $\mathrm{t}$ & $\mathrm{p}$ \\
\hline Female & 29 & 43.27 & 6.21 & 87 & 45 & $>.05$ \\
Male & 60 & 42.60 & 6.7 & & & \\
\hline
\end{tabular}

When table 4 is examined, there is a difference of .67 between female and male students in terms of the average scores obtained from the mathematics anxiety scale. In order to determine whether this difference was significant, t-test was applied to the mean scores of the students and $\mathrm{t}=.45$ was found $\left(\mathrm{t}_{87}=.45<1.99\right)$. This value is below the value of 87 
degrees of freedom .05 is significantly lower than the value of 1.99 at the significance level. According to these values, although there was no significant difference between female students' anxiety scores and mathematics anxiety scores, it was observed that female students' anxiety levels were lower than male students.

Table 5. High school students' mathematics anxiety differences by gender

\begin{tabular}{|c|c|c|c|c|c|c|c|}
\hline Sub-factors & Gender & $\mathrm{N}$ & $\bar{X}$ & Std. Dev. & $\begin{array}{l}\text { Free. } \\
\text { Deg. }\end{array}$ & $\mathrm{t}$ & $\mathrm{p}$ \\
\hline \multirow{2}{*}{$\begin{array}{l}\text { Anxiety from attitude towards } \\
\text { textbooks }\end{array}$} & Female & 29 & 2.18 & .39 & \multirow{2}{*}{87} & \multirow{2}{*}{.44} & \multirow{2}{*}{$>.05$} \\
\hline & Male & 60 & 2.14 & .41 & & & \\
\hline \multirow{2}{*}{ Teachers' anxiety } & Female & 29 & 2.48 & .53 & \multirow{2}{*}{87} & \multirow{2}{*}{.81} & \multirow{2}{*}{$>.05$} \\
\hline & Male & 60 & 2.37 & .63 & & & \\
\hline \multirow[t]{2}{*}{ Exam anxiety } & Female & 29 & 1.24 & .51 & \multirow{2}{*}{87} & \multirow{2}{*}{.3} & \multirow{2}{*}{$>.05$} \\
\hline & Male & 60 & 1.28 & .64 & & & \\
\hline \multirow{2}{*}{$\begin{array}{l}\text { Anxiety from the lack of } \\
\text { secondary school issues }\end{array}$} & Female & 29 & 1.96 & .78 & \multirow[t]{2}{*}{87} & \multirow[t]{2}{*}{.22} & \multirow[t]{2}{*}{$>.05$} \\
\hline & Male & 60 & 2 & .8 & & & \\
\hline \multirow{2}{*}{ Curriculum-related anxiety } & Female & 29 & 2.1 & .94 & \multirow{2}{*}{87} & \multirow{2}{*}{.72} & \multirow{2}{*}{$>.05$} \\
\hline & Male & 60 & 1.96 & .82 & & & \\
\hline
\end{tabular}

When the results of table 5 are examined, t-test was used to test whether there was a statistically significant difference between the averages related to the anxiety caused by the attitude towards the textbooks of high school students and $t$ $=.44$ value was found $\left(\mathrm{t}_{87}=.44<1.99\right)$. There was no significant difference between the genders as 87 degrees of freedom was significantly smaller than the 1.99 table value at .05 significance level. In spite of these data, it was observed that the anxiety level of female students was lower than the anxiety level of male students.

In order to test whether there is a statistically significant difference between high school students' anxiety-related averages and $\mathrm{t}=.81$ value was found $\left(\mathrm{t}_{87}=.81<1.99\right)$. There was no significant difference between the genders as 87 degrees of freedom was significantly smaller than the 1.99 table value at .05 significance level. Despite these data, it was observed that the anxiety level of female students was lower than the anxiety level of male students.

In order to test whether there is a statistically significant difference between the mean scores of the high school students in terms of test anxiety, $\mathrm{t}$-test was performed and $\mathrm{t}=.3$ value was found $\left(\mathrm{t}_{87}=.3<1.99\right)$. There was no significant difference between the genders as 87 degrees of freedom was significantly smaller than the 1.99 table value at .05 significance level. Despite these data, it was seen that the anxiety levels of male students were lower than the female students' anxiety level.

In order to test whether there is a statistically significant difference between high school students' anxiety related to the inadequacy of secondary school subjects, $t$-test was performed and $t=.22$ value was found $\left(t_{87}=.22<1.99\right)$. There was no significant difference between the genders as 87 degrees of freedom was significantly smaller than the 1.99 table value at .05 significance level. In spite of these data, the anxiety level of male students was lower than the anxiety level of female students.

In order to test whether there is a statistically significant difference between high school students' anxiety-related averages according to gender, $\mathrm{t}$-test was performed and $\mathrm{t}=.72$ value was found $\left(\mathrm{t}_{87}=.72<1.99\right.$ ). There was no significant difference between the genders as 87 degrees of freedom was significantly smaller than the 1.99 table value at .05 significance level. Despite these data, it was observed that the anxiety levels of male students were lower than the anxiety level of female students.

\section{Conclusion and Suggestions}

In this study, it was aimed to determine the anxiety levels of high school students towards mathematics lesson and to examine them according to subfactor variables such as textbooks and gender, satisfaction with the teacher, test anxiety, the insufficiency of the secondary school they studied before and the anxiety arising from the curriculum and the following results were obtained:

One of the most frequently examined factors related to mathematics anxiety is gender (Hembree, 1990). Gender factor has been the most important factor that has been investigated to alone but has not yet reached a clear conclusion. 
From the findings of the study, the mathematics anxiety of 9th grade students was examined according to gender. When the differences between general averages in mathematics anxiety were examined, it was seen that the mathematics anxiety levels of female students were lower than that of male students. In addition, it was observed that there was no significant difference in anxiety about the attitudes towards the textbooks, anxiety arising from the attitudes towards the textbooks, anxiety of the teacher, the anxiety of the exam, the anxiety stemming from the inadequacy of the secondary school subjects and the anxiety level of both groups. The results of this research have been done in many research (Ma, 1999; Yuksel-Sahin, 2004; Arikan, 2004; Aydin, 2011; Gierl \& Bisanz, 1995; Lussier, 1996; Dede \& Dursun, 2008; Dursun \& Bindak, 2011; Eskici \& Ilgaz, 2019; Aydin, 2011; Tasdemir, 2015; Yucel \& Koc, 2011; Adal \& Yavuz, 2017; Tuncer \& Yılmaz, 2016; Küçük Demir et al., 2016). However, the findings of our study do not correspond with some research findings. For example; (İlhan \& Sünkür, 2013; Akgün et al., 2007; Arı et al., 2010; Baloğlu, 2004; Ergene, 2011; Şahin, 2008; Baloğlu, 2004b; Baloğlu \& Koçak, 2006; Hemree, 1990; Miller \& Bichsel, 2004), different grade level students' mathematics anxiety in mathematics anxiety and females' level of anxiety is higher, while in some studies (Peker \& Senturk, 2012; Uysal \& Selışık, 2016; Dursun \& Bindak, 2011) higher levels of anxiety in males is observed.

Considering the research results, the following recommendations can be made:

In order to overcome the differences in gender in students' mathematics anxiety; mathematics teachers can avoid gender-related comparisons, and they can be interested in the same diligence as the questions of each student.

According to the interest in mathematics, differences in mathematics anxiety may not be possible. For this reason, mathematics teachers may be more sensitive to all students being involved in mathematics.

In order to overcome the differences arising from the satisfaction of teachers in mathematics anxiety; mathematics teachers can take measures to ensure students' satisfaction. For example; they can give importance to the use of materials in mathematics lesson, prefer to teach by embodying the subjects, be able to have a friendly, patient and tolerant approach to their students, communicate effectively with their students and so on. Considering that students who love mathematics develop a positive attitude towards mathematics lesson, their grades increase and mathematics anxiety decreases; The learning-teaching environment can be organized in such a way that students can learn mathematic. In addition, mathematics teachers can teach mathematics lessons by making use of teaching-learning strategies that center students, making mathematics lessons more enjoyable.

Teaching methods can be revised to alleviate mathematics anxiety. For example, by giving students more say in mathematics courses, students' attitudes towards mathematics can be made positive by taking a student-centered approach, taking a more tolerant approach to failures, and even caring for the smallest successes. This kind of approach can help students gain self-confidence and to experience less anxiety when faced with mathematics (Curtain, 1999). In the research findings, it was emphasized that mathematics anxiety was a congenital problem rather than being learned, and that the teaching methods used increased the mathematics anxiety (Kaja, 2002).

If there is missing information from the secondary school, they must be removed by the mathematics teacher.

If there is a negative situation in the curriculum, this situation should be minimized by the mathematics teacher and the school administration.

In the case of a situation that is not understood in the textbooks or exceeds the level of the students, it should also be corrected by the cooperation of the mathematics teacher and the school administration.

\subsection{Recommendations for Further Research}

This research has been carried out on quantitative and 9th grade students, and in the following research, students' mathematics concerns can be examined in more depth by using qualitative method.

\section{References}

Adal, A. A., \& Yavuz, İ. (2017). The relationship between mathematics self efficacy and mathematics anxiety levels of middle school students. International Journal of Field Education, 3(1), 20-41.

Akgün, A., Gönen, S., \& Aydın, M. (2007). The investigation of anxiety levels of primary school science and mathematics teacher students' according to some variables. Journal of Electronic Social Sciences, 6(20), 283-299.

Alkan, V. (2010). I hate mathematic! Pamukkale University Journal of Education, 28, 189-199.

Alkan, V. (2011). One of the barriers to providing effective mathematics teaching: anxiety and its causes. Pamukkale University Journal of Education, 29(29), 89-107.

Allwright, D., \& Bailey, K. M. (1991). Focus on the Language Classroom: An Introduction to Classroom Research for Language Teachers. Cambridge University Pres, Cambridge. 
Arı, K., Savaş, E., \& Konca, Ş. (2010). Investigation of the causes of mathematics anxiety of 7th grade students. Selçuk University Ahmet Keleşoğlu Journal of Education, 29, 211-230.

Arıkan, G. (2004). The Relationship between the Students' Mathematics Anxiety Levels and Mathematics Achievements Levels. Unpublished Master's Thesis, Gazi University, Ankara, Turkey.

Aydın, B. (2011). A study on secondary school students' mathematıcs anxiety in terms of gender factor. Kastamonu Education Journal, 19(3), 1029-1036.

Aydın, E., Delice, A., Dilmaç, B., \& Ertekin, E. (2009). The influence of gender, grade and institution on primary school mathematics student teachers' anxiety levels. Elementary Education Online, 8(1), 231-242.

Aydın, M., \& Keskin, İ. (2017). The investigation of 8th graders` mathematical anxiety levels in terms of some variables. Kastamonu Education Journal, 25(5), 1801-1818.

Baloğlu, M. (2001). To defeat the fear of mathematics. Journal of Educational Sciences in Theory and Practice, 1(1), 59-76.

Baloğlu, M. (2004). Comparison of mathematics anxiety levels of university students. XIII. National Educational Sciences Congress, 6-9 July, Inonu University, Faculty of Education, Malatya.

Baloğlu, M. (2004a). The relationship between various coping ways and mathematics anxiety. Educational Research, 16, 95-101.

Baloğlu, M. (2004b). Comparison of mathematics anxiety levels of university students. XIII. National Educational Sciences Congress, 6-9 July, Inonu University, Faculty of Education, Malatya.

Baloğlu, M., \& Koçak, R. (2006).A multivariate investigation of the differences in mathematics anxiety. Personality and Individual Differences, 40, 1325-1335. https://doi.org/10.1016/j.paid.2005.10.009

Başarı, D. (1990). "The relationship between test anxiety, state anxiety, academic achievement and exam achievement in middle school students." Unpublished Master Thesis. Ankara: Hacettepe University

Berebitsky, R. D. (1985). An annotated bibliography of the literature dealing with mathematics anxiety. Retrieved ERIC Document Reproduction Service, No: ED 257684.

Bindak, R. (2005b). Comparison of techniques used in item selection in attitude scales. Dicle University Journal of Education, 6(10), 17-26.

Byrd, P. (1982). A descriptive study of mathematics anxiety: its nature and antecedents. (Unpublished Doctoral Dissertation). Indiana University.

Curtain, M. (1999). How to Reduce Mathematics Anxiety in the Classroom at Work and in Everyday Personal Use. New York: Paperback.

Davarcioğlu, P. (2008). The ninth grade students' fear of mathematics in secondary education. Published Master's Thesis, Abant İzzet Baysal University, Social Sciences Institute.

Dede, Y., \& Dursun, Ş. (2008). Elementary education II. examining students' mathematics anxiety levels. Journal of Uludağ University Faculty of Education, XXI(2), 295-312.

Delice, A., Ertekin, E., Aydın, E., \& Dilmaç, B. (2009). Examining the relationship between prospective teachers' mathematics anxiety and knowledge and scientific beliefs. International Journal of Human Sciences, 6(1), 361-375.

Dursun, Ş., \& Bindak, R. (2011). Elementary education II. examining mathematics anxiety of students. C. Ü. Journal of Social Sciences, 35(1), 18-21.

Ergene, T. (2011). The relationships among test anxiety, study habits, achievement, motivation, and academic performance among turkish high school students. Education and Science, 160, 320-330.

Erktin, E., Dönmez, G., \& Özel, S. (2006). Psychometric properties of mathematics anxiety scale. Education and Science, 31(140), 26-33.

Eskici, M., \& Ilgaz, G. (2019). High school students and mathematics in the light of attitude, success and gender. Journal of Social Sciences of Mus Alparslan University, 7(1), 335-345.

Fennema, E., \& Sherman, J. A. (1976). Mathematics attitude scales: instruments designed to measure attitudes toward the learning of mathematics by females and males. JSAS Catalog of Selected Documents in Psychology, 6(31). https://doi.org/10.2307/748467

Gierl, M., \& Bisanz, J. (1995). Anxieties and attitudes related to mathematics in grades 3 and 6. Journal of 
Experimental Education, 63(2), 139-159. https://doi.org/10.1080/00220973.1995.9943818

Harris, A., \& Harris, J. (1987). Reducing mathematics anxiety with computer assisted instruction. Mathematics and Computer Education, 21(1), 16-24.

Hembree, R. (1990). The nature, effects, and relief of mathematics anxiety. Journal for Research in Mathematics Education, 21(1), 33-46. https://doi.org/10.2307/749455

İlhan, M., \& Öner, S. M. (2013). Investigation of predictive power of mathematics anxiety on mathematics achievement in terms of gender and class variables. Journal of Social Sciences of Gaziantep University, 12(3), 427-441.

Isık, E. (1996). Nevrozlar. Kent Printing House, Ankara.

Kaja, P. (2002). "The Sum of All Fears", Pschology Today. 10, 229-223.

Karasar, N. (2005). Scientific Research Method. Ankara: Nobel Publications.

Küçük, D. B., Cansız, Ş., Deniz, D., Çevik, K. C., \& İşleyen, T. (2016). The investigation of primary school teacher candidates' anxiety levels for teaching mathematics in terms of different variables (the example of Bayburt). Bayburt University Journal of Education, 11(2), 379-390.

Kurbanoğlu, N. İ., \& Takunyac1, M. (2012). An investigation of the attitudes, anxieties and self-efficacy beliefs towards mathematics lessons high school students' in terms of gender, types of school, and students' grades. International Journal of Human Sciences, 9(1), 110-130.

Lazarus, M. (1974). Mathophobia: Some personal speculations. National Elementary Principal, 53(2), 16-22.

Lussier, G. (1996). Sex and mathematical background as a predictors of anxiety self efficacy in mathematics. Psychological Reports, 79, 827-833. https://doi.org/10.2466/pr0.1996.79.3.827

Ma, X. (1999). A meta analysis of the relationship between anxiety towards mathematics and achievement in mathematics. Journal for Research in Mathematics Education, 30(5), 520-540. https://doi.org/10.2307/749772

Miller, H., \& Bichsel, J. (2004). Anxiety, working memory, gender, and mathematics performance. Personality and Individual Differences, 37(3), 591-606. https://doi.org/10.1016/j.paid.2003.09.029

Newstead, K. (1998). Aspects of children's mathematics anxiety. Educational Studies in Mathematics, 36(1), 53-71. https://doi.org/10.1023/A:1003177809664

Olkun, S., Altun, A., \& Smith, G. (2005). Computers and 2D geometric learning of Turkish fourth and fifth graders. British Journal of Educational Technology, 36(2), 317-326. https://doi.org/10.1111/j.1467-8535.2005.00460.x

Peker, M., \& Mirasyedioğlu, Ş. (2003). The relationship between high school 2nd grade students' attitudes towards mathematics and their success. Pamukkale University Journal of Education, 2(14), 157-166.

Peker, M., \& Şentürk, B. (2012). An investigation of 5th grade studens' mathematics anxiety in terms of some variables. Journal of Social Sciences of Dumlupinar University, 34, 21-32.

Pintrich, P. R., \& Schunk, D. H. (2002). Motivation in Education: Theory, Research, and Applications. Michigan: Merrill.

Reyes, L. H. (1984). Affective variables and mathematics education. The Elementary School Journal, 84(5), 558-581. https://doi.org/10.1086/461384

Richardson, F. C., \& Suinn, R. M. (1972). The mathematics anxiety rating scale: Psychometric data. Journal of Counseling Psychology, 19(6), 551-554. https://doi.org/10.1037/h0033456

Şahin, F. Y. (2008). Mathematics anxiety among 4th and 5th grade Turkish elementary school students. International Electronic Journal of Mathematics Education, 3(3), 179-192.

Scovel, T. (1991). "The Effect of Affect on Foreign Language Learning: A Review of The Englewood Cliffs, NJ: Prientice Hall.

Suinn, R. M., \& Edwards, R. (1982). The measurement of mathematics anxiety: The mathematics anxiety rating scale for adolescents-MARS-A. Journal of Clinical Psychology, 38(3), 576-580. https://doi.org/10.1002/1097-4679(198207)38:3<576::AID-JCLP2270380317>3.0.CO;2-V

Taşdemir, C. (2015). To investigate the mathematics anxiety levels of secondary students. Batman University Journal of Life Sciences, 5(1), 1-12.

Taylor, B. A., \& Fraser, B. J. (2003). The Influence of Classroom Environment on High School Students' Mathematics Anxiety. Paper presented at th Annual Meeting of the American Educational Research Association, April 21, 
Chicago, IL.

Tekin, H. (1993). Measurement and evaluation in education. Ankara: Judicial Broadcast (7th Edition).

Thomas, R. (1998). A Comparision Between Male and Female Mathematics Anxiety at Community College. Unpublished Master Thesis. Central Connecticut University,

Tobias, S., \& Weissbrod, C. (1980). Anxiety and mathematics: An update. Harvard Educational Review, 50(1), 63-71. https://doi.org/10.17763/haer.50.1.xw483257j6035084

Tuncer, M., \& Yılmaz, Ö. (2016). An evaluation of the secondary school students' opinions on attitudes and anxieties towards mathematics class. Kahramanmaraş Sütçü Imam University Journal of Social Sciences, 13(2).

Uusimaki, L., \& Nason, R. (2004). Causes underlying pre-service teachers' negative beliefs and anxieties about mathematics. Proceedings of the 28th Conference of the International Group for the Psychology of Mathematics Education, 4, 369-376.

Uysal, F., \& Selışık, A. (2016). An investigation about high school students' mathematics anxiety level according to some variables. Journal of Theoretical Educational Science, 9(1), 146-164. https://doi.org/10.5578/keg.10009

Vinson, B. M. (2001). A comparison of pre-service teachers' mathematics anxiety before and after a methods class emphasizing manipulatives. Early Child Education Journal, 29(2), 89-94. https://doi.org/10.1023/A:1012568711257

Yücel, Z., \& Koç, M. (2011). The relationship between the prediction level of elementary school students' mathematics achievement by their mathematics attitudes and gender. Elementary Education Online, 10(1), 133-143.

Yüksel-Şahin, F. (2004). Mathematics fear levels of secondary school students and university students. Educational Sciences and Practice, 3(5), 57-74.

Yüksel-Şahin, F. (2008). Mathematics anxiety among 4th and 5th grade Turkish elementary school students. International Electronic Journal of Mathematics Education, 3(3), 179-192.

\section{Copyrights}

Copyright for this article is retained by the author(s), with first publication rights granted to the journal.

This is an open-access article distributed under the terms and conditions of the Creative Commons Attribution license which permits unrestricted use, distribution, and reproduction in any medium, provided the original work is properly cited. 